УДК 544.137

\title{
Quantum-chemical Research of Endohedral Yttrium Metallofullerenes
}

\author{
Anastasia S. Kholtobina* \\ Darya I. Tsyplenkova ${ }^{\dagger}$ \\ Aleksandr A. Kuzubov ${ }^{\ddagger}$ \\ Maxim A. Visotin ${ }^{\S}$ \\ Aleksandr S. Fedorov $\llbracket$ \\ Kirensky Institute of Physics \\ Akademgorodok, 50/38, Krasnoyarsk, 660036 \\ Siberian Federal University \\ Svobodny, 79, Krasnoyarsk, 660041 \\ Russia
}

Received 01.12.2016, received in revised form 07.03.2017, accepted 26.05.2017

The structural and electronic properties of single molecule $\mathrm{Y} @ \mathrm{C}_{82}$, their join couple and crystal structure of $\mathrm{Y} @ \mathrm{C}_{82}$ were investigated by DFT-GGA approach. The calculations show that $\mathrm{Y} @ \mathrm{C}_{82}$ form stable crystal structures wich may have ferroelectric properties, so they can be applied in electronics as a ferroelectric memory.

Keywords: endohedral metallofullerenes, $\mathrm{Y} @ \mathrm{C}_{82}$, ferroelectric properties, density functional theory. DOI: 10.17516/1997-1397-2017-10-4-422-428.

\section{Introduction}

Endohedral fullerenes are an interesting class of fullerenes because electron transfer from encaged metal atom to carbon cage has been known to occur and this oftentimes alters the electronic and magnetic properties of the fullerenes [1]. Particularly, endohedral yttrium-fullerenes have been obtained by several research groups [2,3]. In 1995, Takata and co-workers performed synchrotron X-ray studies on a powder of $\mathrm{Y} @ \mathrm{C}_{82}$ to confirm the endohedral nature of EMFs for the first time [3]. However, it is still not clear whether the sample contained a pure $\mathrm{Y}_{0} \mathrm{C}_{82}$ isomer or if it was a mixture of two or more regioisomers. Nowadays, the structures of new EMFs can be routinely predicted from the first principles (knowing only a formula of the molecule) with the high reliability rivaling that of singlecrystal X-ray diffraction studies [4]. Potential applications of endodedral fullerenes were also predicted on the basis of their peculiar electronic, physical and chemical properties, including superconductors [5], metallofullerene lasers [5] ferroelectric materials [6,7], nanomemory devices [5] quantum computers, etc. [8].

\footnotetext{
*akholtobina93@mail.ru

†asteralin@gmail.com

†alexxkuzubov@gmail.com

§visotin.maxim@gmail.com

ฯalex99@iph.krasn.ru

(C) Siberian Federal University. All rights reserved
} 


\section{Methods}

The structural and electronic properties of endohedral yttrium-fullerenes were investigated using software package OpenMX (Open source package for Material eXplorer), designed for nano-scale material simulations based on density functional theories (DFT) norm-conserving pseudopotentials, and pseudo-atomic localized basis functions. Simulations of single complex of $\mathrm{Y} @ \mathrm{C}_{82}$, structure, consisting of two complexes of $\mathrm{Y} @ \mathrm{C}_{82}$, and crystal of $\mathrm{Y} @ \mathrm{C}_{82}$ (face centered cubic cell with $\mathrm{a}=11.457 \AA$ ) [9] were performed. Potential barriers of yttrium transitions were then calculated using NEB method. To search a minimum energy path (MEP) in geometrical phase space connecting two stable structures, a nudged elastic band (NEB) method based on is supported in OpenMX. The Monkhorst-Pack [10] k-point Brillouin sampling was used. The $\mathrm{k}$-point grid contained $1 \times 1 \times 1$ points along $\mathrm{a}$, b and $\mathrm{c}$ directions, respectively

\section{Results and discussion}

\subsection{Yttrium positions in fullerene cage}

Since a fullerene molecule has pillow-like shape, an yttrium atom occupies several unequal states into fullerene cavity. All these states, namely high, low1 and low2, that mean the top part of molecule, left and right on the bottom part of molecule, respectively, were investigated (see Fig. 1B). It was found, both low states have the lowest bond energies (-5.154 and $5.152 \mathrm{eV}$,
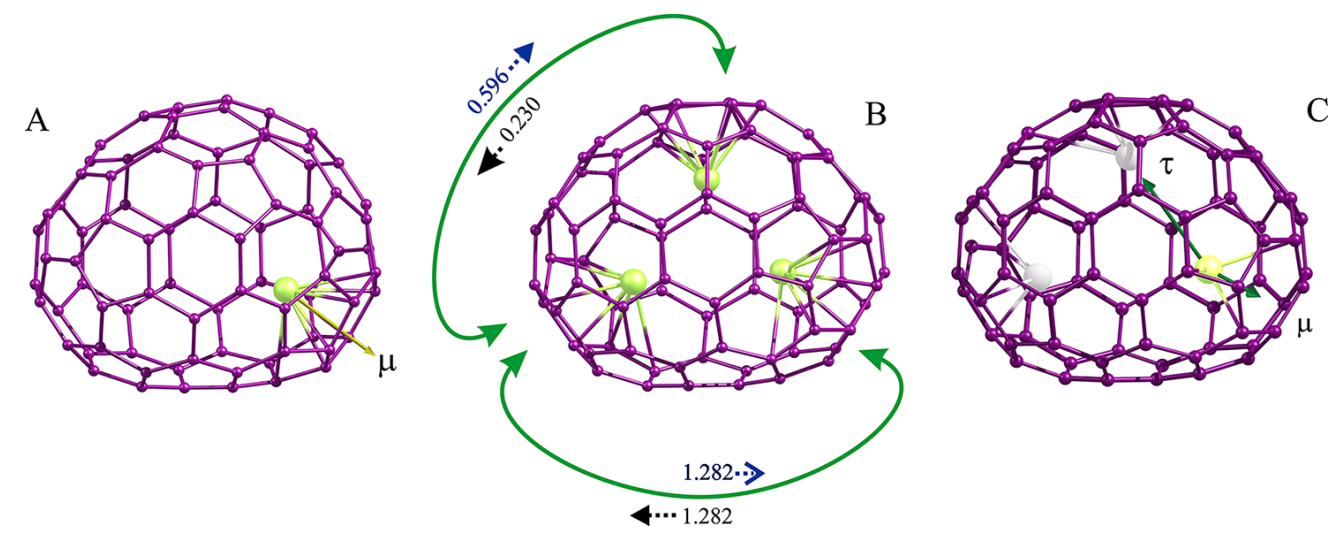

Fig. 1. (A) Direction of the dipole moment for the state 'low', (B) transitions and corresponding energy differenses (eV) of Y atom jump between states 'high'-'low', 'low'-'high', 'low'-'low'; (C) directions of the applied electric field: $\tau$ - along 'high'-'low' states transition, $\mu$ - along the dipole moment direction

respectively), which were calculated by using formula 1, and it indicates their equivalence, while bond energy for state high is $-4.788 \mathrm{eV}$. Moreover, the dipole moment was calculated for systems high and low (2.638 and 2.859 D, respectively).

$$
E_{\text {bond }}=E_{\text {complex }}-E_{f u l}-E_{Y}
$$


where $E_{\text {complex }}$ is total energy of endohedral yttrium-fullerene $\mathrm{Y} @ \mathrm{C}_{82}, E_{f u l}$ is total energy of fullerene, $E_{Y}$ is energy of yttrium atom.

$$
P=\frac{e^{-\frac{\Delta E_{i}}{k T}}}{\sum_{i} e^{-\frac{\Delta E_{i}}{k T}}}
$$

where $\Delta E_{i}$ is difference between total energies of endohedral yttrium-fullerene $\mathrm{Y} @ \mathrm{C}_{82}$ with distinct states of yttrium atom. The population probabilities, calculated by using formula (2), are $2.6 \times 10^{-7}$ and $\sim 0.5$ for high and low, respectively. Since the population probability high is short, the polarizability of the system will be defined by the dipole moment of low state.

Furthermore, the yttrium atom transition barriers between all potential states, namely from high to low, from low to high, from low1 to low2, were studied and values of barriers are 0.230 , 0.596 and $1.282 \mathrm{eV}$, respectively. Consequently, it is more possible, that yttrium atom transition will be performed from state high to low along 111 direction in crystal.

\subsection{Structure, consisting of two complexes of $\mathrm{Y} @ \mathrm{C}_{82}$}

Simulation of endohedral yttrium-fullerenes with all potential states of yttrium atom, signed as high1-high2 (h1h2), low1right-high2 (11rh2), low1right-low2left (11r_l2l), low1left-low2right (11l_l2r), low1left-low2left (11l_12l), were performed for the structure, consisting of two complexes of $\mathrm{Y} @ \mathrm{C}_{82}$, which are arranged as in crystal (see Fig. 2). Among all researched structures the lowest bond energy was found for $11 \mathrm{r} \_121$ geometry $(-5.186 \mathrm{eV})$. Fig. 2 indicates the barriers of all potential transitions of yttrium atom in these structures.

The bond energies, the bond energies of molecule couple (the analogue of crystal lattice energy for structures, consisting of two complexes of $\mathrm{Y} @ \mathrm{C}_{82}$ ) (see Tab. 1) show that the lowest metal bond energy belongs to the geometry with low states of yttrium atom as in case of single molecule. Obviously, the yttrium atom charge insignificantly changes, so only displacement of yttrium atom influences on the dipole moment.

Table 1. The metal bond energies, the bond energies of molecule couple and yttrium atom charges for structures consisting of two complexes of $\mathrm{Y} @ \mathrm{C}_{82}$

\begin{tabular}{|c|c|c|c|}
\hline Structure & $E_{\text {bond_Me }}(\mathrm{eV})$ & $E_{\text {bond_2mol }}(\mathrm{eV})$ & Charge of atom Y (a. u. $)$ \\
\hline h1h2 & -4.800 & -0.034 & 0.428 \\
l1r_h2 & -5.007 & -0.083 & 0.307 \\
\hline l1r_l2l & -5.186 & -0.076 & 0.305 \\
\hline l11_l2r & -5.155 & -0.012 & 0.307 \\
\hline l11_l2l & -5.158 & -0.017 & 0.304 \\
\hline
\end{tabular}

\subsection{Crystal structure of $\mathrm{Y} @ \mathrm{C}_{82}$}

Moreover, the calculations, connected with crystal structure of endohedral yttrium-fullerenes, were executed by analogy with the previous one. In particular, different states of yttrium atom (high, low1, and low2) were investigated and, it was found, that the most advantageous yttrium atom state is low (see Tab. 2). In addition, the crystal lattice energies were calculated for all 

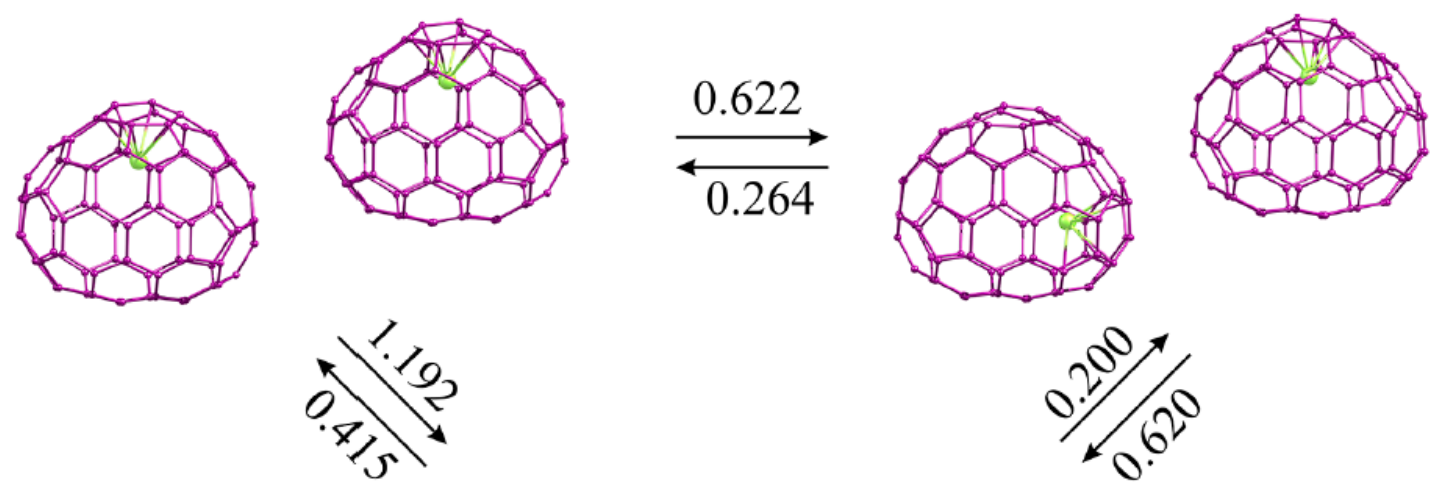
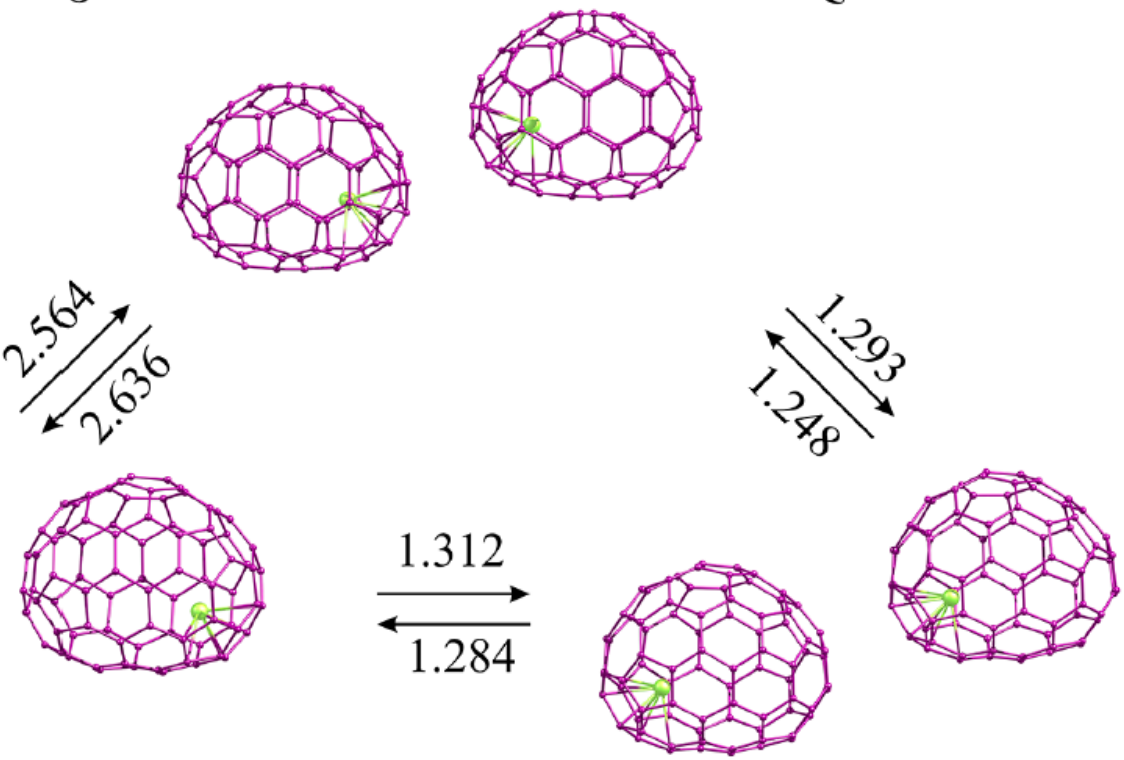

Fig. 2. The potential barriers $(\mathrm{eV})$ of yttrium atom transitions for structures consisting of two $\mathrm{Y} @ \mathrm{C}_{82}$ molecules

crystal structures using formula 3 .

$$
E_{\text {crystal_lat }}=E_{\text {crystal }}-n E_{\text {complex }}
$$

where $E_{\text {crystal }}$ is total energy of crystal model, $n$ is number of molecules $\mathrm{Y}_{82} \mathrm{C}_{82}$ in crystal model, $E_{\text {complex }}$ is total energy of $\mathrm{Y}_{0} \mathrm{C}_{82}$

In addition, a correlation was obtained between the dipole moment and the electric field and the correlation between the yttrium atom charge and the electric field. Furthermore, the electric field was applied along two directions (see Fig. 1C), the first of them runs along the transition from state high to one low, and the second one runs along the dipole moment direction. It was found, the first and the second directions correspond to the complex and linear dependences (see Fig. 3). With respect to the yttrium atom charge, electric field correlation in the case of electric field applied along the dipole moment direction, charge stops increasing and remains constant in contradistinction to case of electric field applied along the transition from state high to low.

The research of transition barriers from state high to low $(0.661 \mathrm{eV})$ and from low1 to low2 (1.229) has shown that they insignificantly differ from analog transition barriers in sin- 
gle molecules (see Fig. 1). It is interesting to note that in this case synchronous displacement of yttrium atoms descents in all endohedral yttrium-fullerenes. Also, the values of the transition barriers are comparable to those of common ferroelectric materials (e.g. $0.44 \mathrm{eV}$ in potassium dihydrogen phosphate [11] ), thus, such fullerene crystal structures can be considered as a promicing material for ferroelectric applications. Furthermore, the crystal model of $\mathrm{Y} \mathrm{C}_{82}$ comprises four endohedral yttrium-fullerenes, which are arranged as in the face-centered lattice. The displacement of one yttrium atom from state high to low was investigated in this model (see Fig. 4). The yttrium atom transition barrier between potential states, namely from A to C, was studied and value of barrier are $1.127 \mathrm{eV}$.

Table 2. The metal bond energies, the crystal lattice energy and yttrium atom charges for crystals of $\mathrm{Y} @ \mathrm{C}_{82}$

\begin{tabular}{|c|c|c|c|}
\hline Structure & $E_{\text {bond_Me }}(\mathrm{eV})$ & $E_{\text {cryst }}(\mathrm{eV})$ & Charge of atom Y (a. u.) \\
\hline high & -5.240 & -0.452 & 0.424 \\
\hline low1 & -5.610 & -0.458 & 0.295 \\
\hline low2 & -5.579 & -0.425 & 0.299 \\
\hline
\end{tabular}
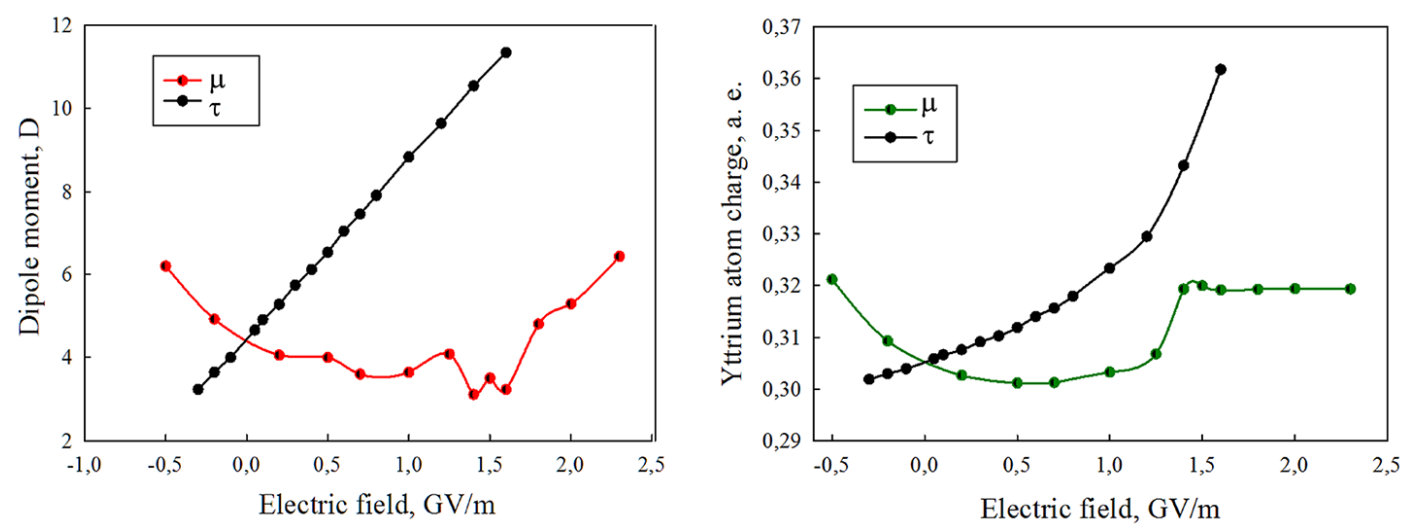

Fig. 3. The dipole moment electric field (a) and $\mathrm{Y}$ atom charge electric field dependencies (b) for different directions of applied field: $\tau$ is along 'high'-'low' states transition, $\mu$ is along the dipole moment direction

\section{Conclusion}

Endohedral yttrium-fullerenes $\mathrm{Y} @ \mathrm{C}_{82}$ simulations result in formation of stable structures like $\mathrm{Y} @ \mathrm{C}_{82}$, both in the form of a single molecule and a crystal. The most favorable positions of $\mathrm{Y}$ atom inside the carbon cage are similar in the each type of structures, confirming the common trend in all researched models. Furthermore, the transitions barriers also indicate that $\mathrm{Y}$ atom tends to occupy the same positions. It is interesting to note that ferroelectric properties were found in crystal structure. The complex and linear dependences were obtained for electric field applied along the transition from state high to low and for electric field applied along the 
A

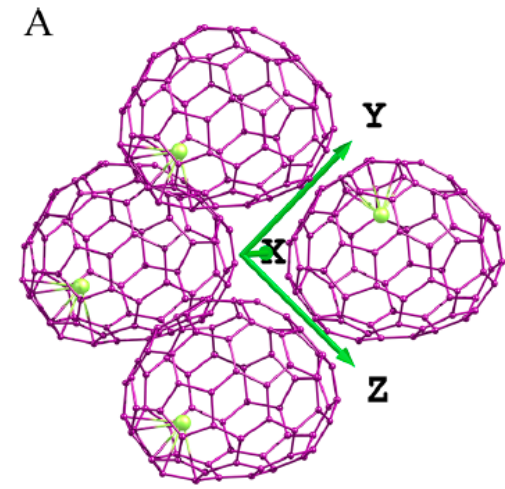

B

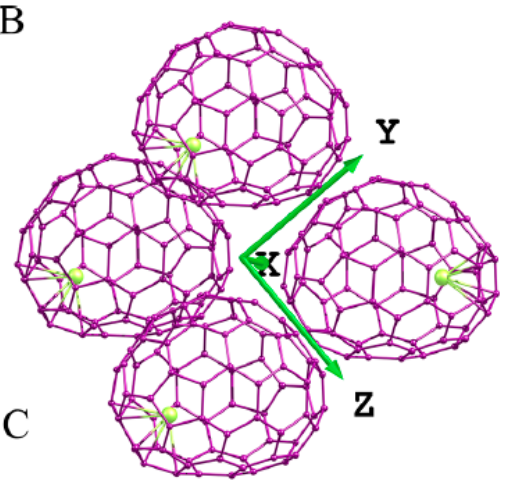

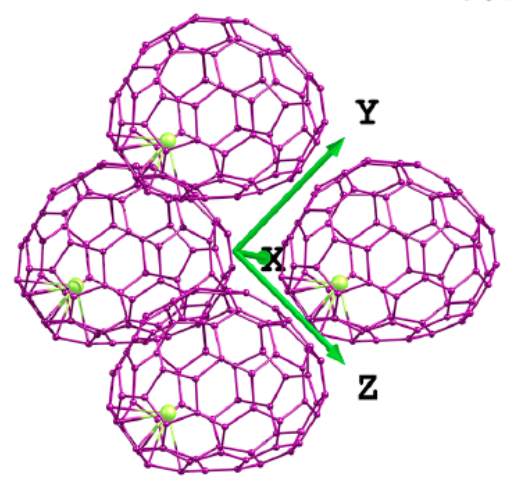

Fig. 4. The geometries of crystal model $\mathrm{Y} @ \mathrm{C}_{82}$ with different yttrium atom positions in fullerene cage

dipole moment direction, respectively. Researching of the yttrium atom charge - electric field correlation indicated that in the case of electric field applied along the dipole moment direction charge stops increasing and remains constant. Endohedral yttrium-fullerenes $\mathrm{Y}_{8} \mathrm{C}_{82}$ can be applied in radiotronics and automatics and the development of piezoelectric devices, condensers and temperature gages.

This work was supported by the Russian Foundation for Basic Research (no. 16-43-242148), Krasnoyarsk Regional Science Foundation (agreement 35/16 dated 18.11.2016) and by the president of Russia Scientific School program NSh 7559.2016.2.

\section{References}

[1] S.Yung, C.-R.Wang, Word Scientific, 2014.

[2] M.M.Ross, H.H.Nelson, J.H.Callahan, S.W.McElvany, J. Phys. Chem., 96(1992), 5231.

[3] S.W.McElvany, J. Phys. Chem., 96(1992), 4935.

[4] M.Takata, B.Umeda, E.Nishibori, M.Sakata, Y.Saitot, M.Ohno, H.Shinohara, Nature, $\mathbf{3 7 7}(1995), 46-49$.

[5] L.Bao, C.Pan, Z.Slanina, F.Uhlik, T.Akasaka, X.Lu, Angew. Chem. Int. Ed., 55(2016), 1-6. 
[6] D.S.Bethune, R.D.Johnson, J.R.Salem, M.S.Devries, C.S.Yannoni, Nature, 366(1993), 123.

[7] J.J.Cioslowski, Am. Chem. Soc., 113(1992), 4139.

[8] A.A.Popov, S.Yang, L.Dunsch, Chemical reviews, 113(2013), 989-6113.

[9] H.Suematsu, Y.Murakami, H.Kawata, Y.Fujii, N.Hamaya, O.Shimomura, K.Kikuchi, Y.Achiba, I.Ikemoto, Mat. Res. Soc. Symp. Proc., 349(1994), 01994.

[10] H.J.Monkhorst, J.D.Pack, Phys. Rev. B, 13(1976), 5188.

[11] B.A.Strukov, I.V.Shaidshtein, T.V.Pavlovskaya, S.V.Grabovskii, Y.Uesu, M.Fukunaga, L.Carman, Ferroelectrics, 267(2002), 329.

\section{Квантово-химическое исследование эндоэдральных иттриевых металлофуллеренов}

Анастасия С. Холтобина Дарья И. Цыпленкова Александр А. Кузубов Максим А. Высотин Александр С. Федоров Институт физики им. Л. В. Киренского СО РАН Академгородок, 50/38, Красноярск, 660036

Сибирский федеральный университет Свободный, 79, Красноярск, 660041

Россия

Структурные и электронные свойства одиночного комплекса $\mathrm{Y} @ \mathrm{C}_{82}$, структуры, состолщей из двух комплексов $\mathrm{Y} @ \mathrm{C}_{82}$, а также данного комплекса в периодических условиях были исследованы в рамках DFT-GGA-подхода. Моделирование эндоэдральных металлофуллеренов Ү@ $\mathrm{C}_{82}$ показало возможность формирования из них стабилъных кристаллических структур, которые обладают сегнетоэлектрическими свойствами, что может быть применено в электронике и сегнетоэлектрической памяти.

Ключевые слова: эндоэдральные металлофуллерены $\mathrm{Y} @ \mathrm{C}_{82}$, сегнетоэлектрические свойства, метод функционала плотности. 